\title{
THE STUDY OF TRANSFORMED HERBACEOUS VEGETATION IN THE AREA FLOODED DUE TO COAL MINE WORKINGS
}

\author{
YURIY LYKHOLAT $\varpi^{1}$, NINA KHROMYKH ${ }^{2}$, OLEH DIDUR ${ }^{2}$, OLEKSANDR KOTOVYCH ${ }^{3}$, IGOR KOVALENKO $^{4}$, \\ VLADYSLAV KOVALENKO ${ }^{5}$, OLEXANDER TSYLIURYK ${ }^{6}$, TETYANA LYKHOLAT ${ }^{7}$
}

\begin{abstract}
${ }^{1}$ Department of Plant Physiology and Introduction, Faculty of Biology and Ecology, Oles Honchar Dnipro National University, Gagarin Ave. 72 , 49010 Dnipro, Ukraine; e-mail: Lykholat2006@ukr.net

${ }^{2}$ Laboratory of Plant Physiology and Molecular Biology, Biology Research Institute, Oles Honchar Dnipro National University, Gagarin Ave. 72,49010 Dnipro, Ukraine; e-mail: khromykhN@ukr.net; didur@i.ua

${ }^{3}$ Department of Geobotany, Soil Science and Ecology, Faculty of Biology and Ecology, Oles Honchar Dnipro National University, Gagarin Ave. 72, 49010 Dnipro, Ukraine; e-mail: bgz@ua.fm

${ }^{4}$ Department of Ecology and Botany, Faculty of Agricultural Technologies and Environmental Use, Sumy National Agrarian University, Kondrat eva Str. 160, 40021 Sumy, Ukraine; e-mail: kovalenko_977@ukr.net

${ }_{5}^{5}$ Department of Biotechnology and Phytopharmacology, Faculty of Agricultural Technologies and Environmental Use, Sumy National Agrarian University, Kondrat'eva Str. 160,40021 Sumy, Ukraine; e-mail: tovagrarne_bz@ukr.net

${ }^{6}$ Department of Crop growing, Faculty of Agronomy, Dnipro State Agrarian and Economic University, Serhii Efremov Str. 25, 49600 Dnipro, Ukraine; e-mail: tsilurik_alexander@ukr.net

${ }^{7}$ Department of Microbiology, Virology and Biotechnology, Faculty of Biology and Ecology, Oles Honchar Dnipro National University, Gagarin Ave. 72 , 49010 Dnipro, Ukraine; e-mail: Lyktata89@ukr.net
\end{abstract}

$\bowtie$ Corresponding author

Received: 14 May 2020 / Accepted: 21 September 2020

Abstract

Lykholat Y., Khromykh N., Didur O., Kotovych O., Kovalenko I., Kovalenko V., Tsyliuryk O., Lykholat T.: The study of transformed herbaceous vegetation in the area flooded due to coal mine workings. Ekológia (Bratislava), Vol. 40, No. 3, p. 222-229, 2021.

\begin{abstract}
The spontaneous vegetation in permanent flooding zone around technogenic water bodies arising on former pastures due to underground coal mining in the Western Donbass basin (steppe zone of Ukraine) was studied in 2018-2019. Occurrence and abundance of herbaceous plants were taken into account in 36 vegetation plots over a total area of $0.8 \mathrm{~km}^{2}$ in different habitats: dry, wet and flooded. In total, 83 plant species belonging to 31 families and 66 genera were identified, among which perennials dominated. Strong negative Pearson's correlation was found between the amount and abundance of plant species and soil characteristics across the studied habitats, where the joint action of all edaphic factors determined the mosaic appearance of transformed vegetation. The spontaneous vegetation of the least disturbed xero-mesophilic habitats was most similar to (semi)natural grasslands, while the vegetation of hygrophilic habitats had a complete mismatch. Surrounding grasslands were not the most important diasporas' source for spontaneous succession in the disturbed zone, and many species were supposed to come from the more remote areas. Recovery of target vegetation did not occur for 25 years of permanent subsidence and flooding due to radical transformation of landscape and soil and appearance of completely inappropriate habitats. At the same time, the unusual species composition of spontaneous vegetation and significant number of rare and endangered plants indicate the formation of valuable biotopes in the subsidence and flooding zone.
\end{abstract}

Key words: herbaceous plants, flooding, succession, target vegetation, habitat types.

\section{Introduction}

Mine activity contributes to landscape modification and concomitant habitat fragmentation, which are key factors in the global extinction of species (Fischer, Lindenmayer, 2007; Wilson et al., 2016; Zhang et al., 2019). The need to restore vegetation in mining areas is a serious challenge, and optimal solution can be found based on a combination of the natural capabilities of damaged areas with spontaneous colonisation processes (Kirmer et al., 2008; Baasch et al., 2012; Cross et al., 2018). In recent years, much attention has been paid to restoration successions on various transformed landscapes, including ruderal urban areas, abandoned fields and uprooted forests (Prach et al., 2017), and abandoned mined peatlands (Poulin et al., 2005; Graf et al., 2008; Konvalinková, Prach, 2010). Primary successions have been studied in dumps of coal mines (Moreno-de las Heras et al., 2008; Bian et al., 2010), spoil heaps from uranium mining (Burke, 2018), gravel and sand pits (Řehounková, Prach, 2006; Trnkova et al., 2010). Environmental colonisation plays a decisive role in the succession in technogenic ecotopes, with the additional introduction of plant seeds providing faster formation of vegetation cover (Baasch et al., 2012). 


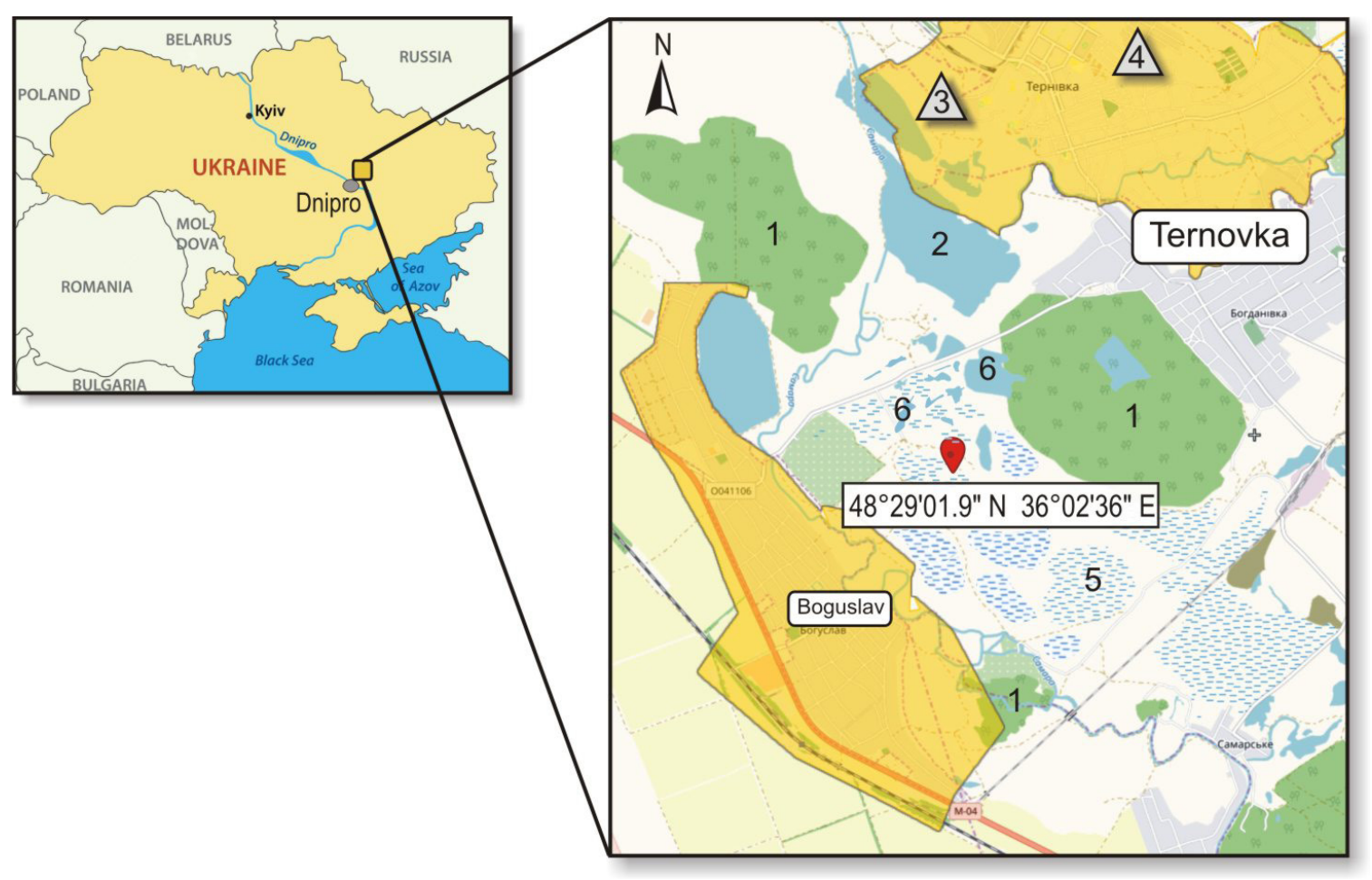

Fig. 1. Map of the research area indicating the zone of surface subsidence due to underground coal mining and the formation of technogenic water bodies: 1 - (semi)natural forests, 2 - river spill, 3, 4 - coal mines, 5 - grasslands, 6 - technogenic water bodies.

In Ukraine, transformed vegetation in the Western Donbass coal basin was studied mainly in connection with successions in the areas occupied by mine dumps, where the artificial communities of woody plants were created on bulk soils at the end of the last century (Travleyev et al., 2005). Herbaceous vegetation changes in slightly flooded pastures included increase in share of halophytic and ruderal species (Bezrodnova, 2000). Over the past quarter century, environmental disruptions have led to the formation of technogenic water bodies (Gorova et al., 2013), a radical change in soil nature and the habitat of plants in general. We assumed that successional trajectory in the area of permanent flooding due to mine workings should differ from both primary successions in technogenic ecotopes and secondary successions that occur after the termination of disturbances. This work addresses the following issues: (i) the species composition of herbaceous vegetation in the zone of permanent technogenic flooding and (ii) the potential syngenetic series of herbaceous communities in the zone of permanent flooding.

\section{Material and methods}

The studies were carried out in 2018-2019 in the territory of the Western Donbass coal basin (Dnipropetrovsk province, steppe zone of Ukraine). The result of many years of mine activity is changes in the regional landscape, which entailed subsidence of the earth's surface, flooding and the emergence of technogenic water bodies, which can be recorded using satellite imagery (Fig. 1).

The climate of the region has continental features with sharp fluctuations in temperature and strong winds. High volatility is 2-3 times higher than the annual rainfall, which averages 472 $\mathrm{mm}$, but can drop to $250 \mathrm{~mm}$ in dry years. The average air temperature varies from $-7.5^{\circ} \mathrm{C}$ in January to $+21.5^{\circ} \mathrm{C}$ in July.

Soil samples were taken from the zone of the most development of the herbaceous plants root system from a depth of 50 $\mathrm{cm}$ with an interval of $10 \mathrm{~cm}$ and analysed in accordance with the 'Soil Sampling and Methods of Analysis' (Carter, Gregorich, 2008).

Zonal herbaceous vegetation has not been preserved much, since today agricultural land occupies $80 \%$ of the Dnipropetrovsk province area (Ecological passport, 2018) and the rest of the area contains technogenic landscapes spontaneously populated by alien plant species (Alexeyeva et al., 2016; Baranovski et al., 2016; Lykholat et al., 2018). Vegetation study in the subsidence and flooding zone on an area of $0.8 \mathrm{~km}^{2}$ was carried out using the sample area method during April-August. Three different types of plant habitats were identified: dry (site 1, xero-mesophilic), wet (site 2, mesophilic and site 3, meso-hygrophilic) and flooded (site 4 , hygrophilic). In total, 36 vegetation records were done using plots of size $100 \times 100 \mathrm{~cm}$ along nine transects around three technogenic ponds. Vegetation in the adjacent area within a radius of $100 \mathrm{~m}$ from the subsidence zone (control site, xerophilic) was studied to account for herbaceous plant species that could be a source of diasporas for spontaneous succession.

Plant species abundance was evaluated visually on a BraunBlanquet scale interpreted by Trnkova et al. (2010) as follows: 1 - very rare, 2 - rare, 3 - scattered, 4 - abundant and 5 - very abundant.

Target plant species (typical of grasslands on soils subject to salinisation processes) as well as specialists (preferring certain habitats) and generalists (occurred in different habitats) were 


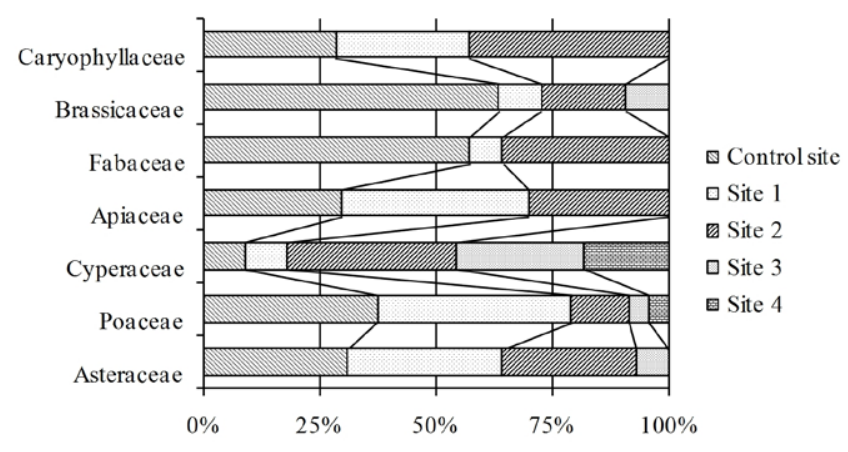

Fig. 2. Differences in distribution of the families with the largest species amount in the taxonomic structure of plant communities in the undisturbed territory (control site) and in the subsidence and flooding area (sites 1-4).

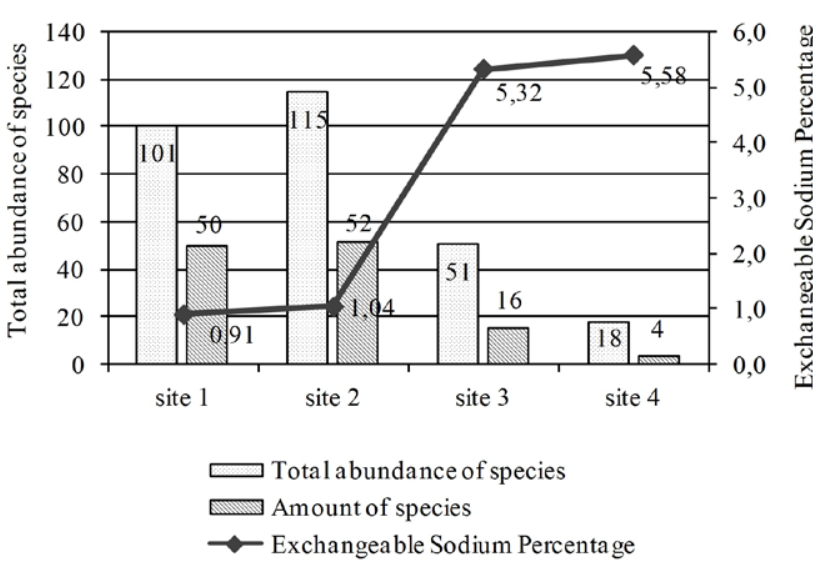

Fig. 3. The influence of the soil exchangeable sodium level on the distribution of total amount and abundance of herbaceous plant species in different sites on the transformed area. The gradients of other soil characteristics had a similar effect.

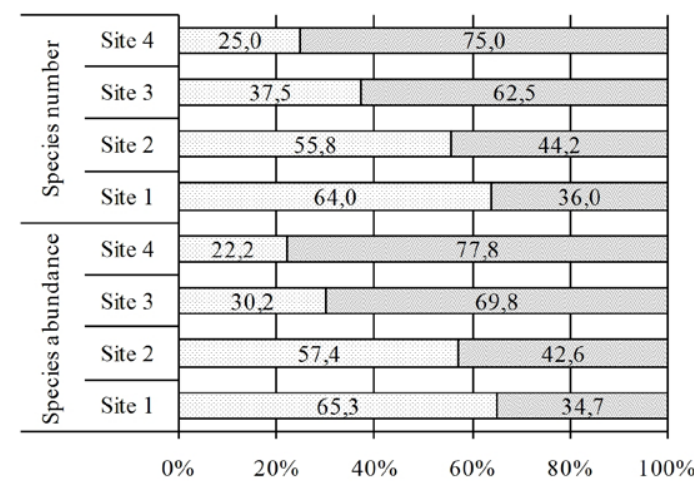

$\square$ Generalists $\square$ Specialists

Fig. 4. Distribution of the number and abundance of herbaceous plant species in different sites of the transformed territory with respect to the ecological specialisation of species. determined on the basis of catalogues 'Flora of the USSR' (19351965) and 'Flora of the European part of the USSR' (1974-1989) and regional vegetation database (Tarasov, 2012; Baranovski et al., 2016; Baranovsky et al., 2017).

Status of rare and protected plants was established in accordance with European (Bilz et al., 2011), national (Didukh, 2009) and regional (Travleyev, 2010) Red lists.

Nomenclature of plant species corresponds to the International Code of Botanical Nomenclature (Hoch, 1999), updated by Mosyakin and Fedoronchuk (1999).

Indicators of plant species number and abundance as well as soil study results were subjected to analysis of variance (ANOVA). Tukey's honestly significant difference (HSD) test was used to verify differences between the sites with respect to vegetation and soil characteristics, performing calculation in the Statgraphics Centurion XV Version 15.1.02 package. Pearson's correlation indicated the dependence of number and abundance of herbaceous plant species on the soil properties in different habitats. $P$ values $\leq 0.05$ were considered statistically significant.

\section{Results}

In total, 83 species of herbaceous plants belonging to 31 families and 66 genera were identified in spontaneous vegetation in the zone of surface subsidence and permanent technogenic flooding. Of these, 8 families ( 25 plant species) belong to the class of monocotyledons and 23 families (58 plant species) belong to the class of dicotyledons. The group of families with high species richness included only seven families consisting of three or more species and was headed by Asteraceae and Poaceae, accounting for 19 and 11 plant species, respectively (Fig. 2).

The families Alliaceae, Boraginaceae, Chenopodiaceae, Iridaceae, Lamiaceae, Plantaginaceae and Ranunculaceae were represented by two species. The largest group covered 17 families having only one species (Aristolochiaceae, Asclepiadaceae, Asparagaceae, Campanulaceae, Convolvulaceae, Euphorbiaceae, Fumariaceae, Geraniaceae, Juncaceae, Liliaceae, Limoniaceae, Polygonaceae, Resedaceae, Rubiaceae, Scrophulariaceae, Solanaceae and Typhaceae).

Wintering species significantly prevailed in the spontaneous vegetation, and the perennials constituted the most numerous and abundant group of species both as a whole in the disturbed area and in each of the sites (Table 1).

A statistically significant strong negative Pearson's correlation $(P<0.05)$ was found between the number and abundance of herbaceous species in different sites of the subsidence and flooding zone and the environmental characteristics of the topsoil such as salinity level, water content and exchangeable sodium percentage (Table 2).

The gradient growth of soil properties' indicators in the direction from the subsidence zone periphery to the technogenic water bodies was associated with a decrease in the total number of herbaceous plant species. The negative linear relationship between soil acidity and the number of plant species turned out to be statistically unreliable $(P>0.05)$.

Vegetation study along the transect from the flooding zone periphery to the technogenic ponds showed a significant decrease in the amount and abundance of herbaceous plant species, concomitant with the growth of all topsoil characteristics (Fig. 3). 
Table 1. Herbaceous species distribution with respect to life histories and plant species abundance in all studied sites according to the Tukey's criterion (Mean \pm SE, $n=3, P<0.05$ ).

\begin{tabular}{|l|c|c|c|c|c|}
\hline \multirow{2}{*}{ Marker } & \multicolumn{5}{|c|}{ Species amount (\% of total) } \\
\cline { 2 - 6 } & At all areas & Site 1 & Site 2 & Site 3 & Site 4 \\
\hline Annual & $6(7.2)$ & $3(6.0)$ & $2(3.9)$ & $2(12,5)$ & - \\
\hline Biennial & $11(13.3)$ & $7(14.0)$ & $11(21.1)$ & $1(6.2)$ & - \\
\hline Perennial & $66(79.5)$ & $40(80.0)$ & $39(75.0)$ & $13(81.3)$ & $4(100.0)$ \\
\hline Total species abundance & & $101 \pm 4.04^{\mathrm{a}}$ & $115 \pm 4.04^{\mathrm{ab}}$ & $51 \pm 2.52^{\mathrm{c}}$ & $18 \pm 1.00^{\mathrm{d}}$ \\
\hline
\end{tabular}

Note: The same letters in Latin indicate statistically insignificant differences in the average values of the compared pair of the sites, according to the Tukey's criterion (HSD test).

Table 2. Pearson's correlation of the amount and abundance of herbaceous plant species with the topsoil characteristics in different sites on the transformed area.

\begin{tabular}{|l|c|c|c|c|c|}
\hline \multicolumn{1}{|c|}{ Index } & $\begin{array}{c}\text { Statistical } \\
\text { indicator }\end{array}$ & $\begin{array}{c}\text { Soil acidity } \\
\text { (pH aq.) }\end{array}$ & $\begin{array}{c}\text { Salinity, } \\
\mathbf{\%}\end{array}$ & $\begin{array}{c}\text { Water content, } \\
\text { mm } \mathbf{H}_{2} \mathbf{O}\end{array}$ & $\begin{array}{c}\text { Exchangeable } \\
\text { sodium percentage }\end{array}$ \\
\hline \multirow{2}{*}{$\begin{array}{l}\text { Total number of species along the gradients } \\
\text { of soil properties }\end{array}$} & Correlation & -0.89 & -0.99 & -0.94 & -0.98 \\
\cline { 2 - 6 } & $P$-values & 0.109 & 0.011 & 0.060 & 0.0169 \\
\hline \multirow{2}{*}{$\begin{array}{l}\text { Total abundance of species along the } \\
\text { gradients of soil properties }\end{array}$} & Correlation & -0.90 & -0.96 & -0.94 & -0.95 \\
\cline { 2 - 6 } & $P$-values & 0.103 & 0.039 & 0.061 & 0.051 \\
\hline
\end{tabular}

Table 3. Similarity of species composition between undisturbed herbaceous vegetation (control site) and spontaneous vegetation in different sites on the subsidence and flooding zone.

\begin{tabular}{|l|c|c|c|c|c|}
\hline Habitat & Control site & Site 1 & Site 2 & Site 3 & Site 4 \\
\hline Control site & - & 26 & 19 & 1 & 0 \\
\hline Site 1 & $31.3 \%$ & - & 29 & 4 & 0 \\
\hline Site 2 & $20.7 \%$ & $39.7 \%$ & - & - & 0 \\
\hline Site 3 & $1.4 \%$ & $6.5 \%$ & $11.5 \%$ & $17.6 \%$ & 3 \\
\hline Site 4 & 0 & 0 & 0 & - \\
\hline
\end{tabular}

Note: Matrix upper part is the number of common plant species in the compared pair; the lower part is the value of the Jacquard coefficient.

In spontaneous vegetation, 31 herbaceous plants were identified as the target species (xerophytic steppe and meadow herbs growing on saline-prone soils). Jacquard correlation indicates significant differences in plant species composition in the subsidence and flooding zone in comparison with the surrounding herbaceous vegetation (Table 3 ).

The greatest similarity with the undisturbed vegetation was found for site 1 (xero-mesophilic habitat with insignificant surface subsidence), while the similarities were much smaller in a more saline and humid habitat (site 2). The herbaceous species composition in site 3 (meso-hygrophilic habitat with salt marshes) was very different from the undisturbed one, and a complete dissimilarity with the surrounding vegetation was established for site 4 (hygrophilic habitats on the banks of technogenic ponds).

Almost equal number of specialists and generalists was found in the total area (50.6\% and $49.4 \%$, respectively). However, the ratio of these categories of herbaceous plants varied across the studied sites of subsidence and flooding zone (Fig. 4).

An analysis of the propagules dispersal methods by the herbaceous species that were identified in vegetation on the dis- turbed area showed more significant proportion of species using anemochoria among non-target species in comparison with the target group (32.7\% of all against $12.9 \%$ of all). In addition, the non-target group contained two species distributed by zoohoria, which were absent among the target species. The proportion of species that preferred autochoria was higher in the group of target species compared to non-target species $(83.9 \%$ of all versus $61.5 \%$ of all), and only one species used hydrochoria both in groups of target and non-target species.

The group of herbaceous plants that are vulnerable, rare and require protection, found in the territory of subsidence and flooding zone, accounted for nine species (10.8\% of all), which are currently included in various lists in order to preserve them (Table 4).

The list of synanthropic plants that occurred in the spontaneous vegetation consisted of 18 species (21.7\% of all), of which 9 species were the non-native herbaceous plants. Among them, six species were naturalised archaeophytes (Artemisia absinthium, Consolida regalis, Cynoglossum officinale, Fumaria schleicheri, Lactuca serriola and Thlaspi arvense), two were naturalised neo- 
Table 4. List of endangered and rare plant species founded in spontaneous vegetation on the territory of permanent technogenic flooding zone.

\begin{tabular}{|l|l|}
\hline Species & Conservation status and category \\
\hline Allium regelianum A. Becker ex Iljjn & ERL (R), RDBU (R), RDBDP (1) \\
\hline Allium praescissum Rchb. & RDBDP (2) \\
\hline Chartolepis intermedia Boiss. & $\operatorname{RDBDP}(3)$ \\
\hline Elytrigia elongata (Host) Nevski & $\operatorname{RDBDP}(3)$ \\
\hline Fritillaria meleagroides Patrin ex Schult. \& Schult. F & $\operatorname{RDBU}(\mathrm{V}), \operatorname{RDBDP}(2)$ \\
\hline Gladiolus tenuis M. Bieb. & $\mathrm{RDBU}(2), \operatorname{RDBDP}(2)$ \\
\hline Iris halophylla Pall. & $\mathrm{RDBDP}(3)$ \\
\hline Rhaponticum serratuloides (Georgi) Bobrov & $\operatorname{RDBDP}(3)$ \\
\hline Stipa pennata L. & $\mathrm{RDBU}(\mathrm{V}), \operatorname{RDBDP}(2)$ \\
\hline
\end{tabular}

Notes: ERL - European Red List; RDBU - Red Book of Ukraine; RDBDP - Red Book of Dnipro Province.

phytes (Asclepias syriaca and Reseda lutea) and one species was a casual neophyte (Hyoscyamus niger). The origin area of most of the alien species is the Mediterranean Region, except Asclepias syriaca which was introduced from North America. The remaining 25 non-target herbaceous plants (30.1\% of all species) were classified as halophytes or wetland plants according to their ecological features.

\section{Discussion}

Study results show varying disturbance degrees of soil and hydrological conditions in the subsidence and flooding zone, which led to a radical change in herbaceous vegetation as compared to the undisturbed area. Landscape factors can have a de-

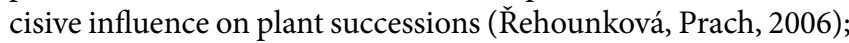
therefore, species composition of spontaneous vegetation in the flood zone is a result of the action of mosaic landscape as an environmental filter (Čeplová et al., 2015; Herben et al., 2016). Spontaneous vegetation contains ecologically distant species (xerophytic steppe plants, mesophytic meadow species and wetland plants) that inhabit neighbouring sites with varying degrees of environmental damage.

The relatively low similarity of the flood zone vegetation with the surrounding (semi)natural grassland and the significant presence of atypical herbaceous plants are explained by the properties of different habitats. Our results are consistent with data of Moreno-de las Heras et al. (2008) on succession in mine dumps, where the presence of well-preserved surrounding vegetation becomes decisive for colonisation only in the absence of serious restrictions on soil indicators. Probably, species pool in the surrounding undisturbed area was not the only and was not even the main source of diasporas for spontaneous succession in subsidence and flooding zone, and many plant species came from more distant areas. This assumption is consistent with the report of Kirmer et al. (2008) on the probability of emergence of rare plant species in disturbed mine sites located at a distance of more than 10 from seed sources.

Diaspora distribution methods characteristic of plant species found in the disturbed area include the active use of autochoria and anemochoria (especially a group of non-target species) and less significant participation of hydrochoria and zoohoria. However, the high abundance of autochor at the most disturbed sites inhabited by halophytes and wetland plants suggests the possibility of the diasporas' distribution in several ways, which is consistent with the concept of Sádlo et al. (2018) on different species distribution strategies combining several methods.

A high percentage of non-target species belonging to different ecological groups shows that during spontaneous succession, the main role was played not by the diasporas' availability, but by the presence of suitable habitats. Thus, the local habitat conditions determined the mosaic nature of the spontaneous herbaceous vegetation on the disturbed territory. Similar findings were made by Prach et al. (2017) that the composition of plant species in disturbed habitats depends on the species ability to survive the disturbance or populate the disturbed area. The established dependence of the vegetation structure in different sites of the subsidence and flooding zone on the degree of habitat transformation is consistent with the concept of Herben et al. (2016) on the species response to the frequency and severity of habitat disturbances in which individual species may occur.

In spontaneous vegetation, almost the same amount of species preferring a particular type of habitat (specialists) and species found in several different habitats (generalists) were found. Using the approach and terminology of Zelený and Chytrý (2019), we took into account that this separation of species is relative, but applicable for the vegetation analysis. The plant species Achillea millefolium and Taraxacum officinale, which we attributed to the generalists, were identified by Prach et al. (2017) among the most common and, consequently, successful colonisers of disturbed territories. The species Phragmites australis, Verbascum densiflorum, Tanacetum vulgare and Convolvolus arvensis, founded in the vegetation in the flood zone, were classified as generalists, which coincides with the assessment of these species given by Zelený and Chytrý (2019). The ratio of the number and abundance of specialists and generalists at different sites of flood zone reflects the role of different herbaceous plants in mosaic vegetation cover at the disturbed area. In habitats that provide a wider range of ecological conditions and therefore have a large species diversity (xero-mesophilic and mesophilic sites), high abundance was achieved both by specialists (Artemisia santonica, Chartolepis intermedia, Glechoma hederacea, Allium regelianum) and generalists (species of genera Carex and Eryngium, Elytrigia repens, Euphorbia virgata, Galium verum, Verbascum densiflorum). In the meso-hygrophilic site, the main species richness 


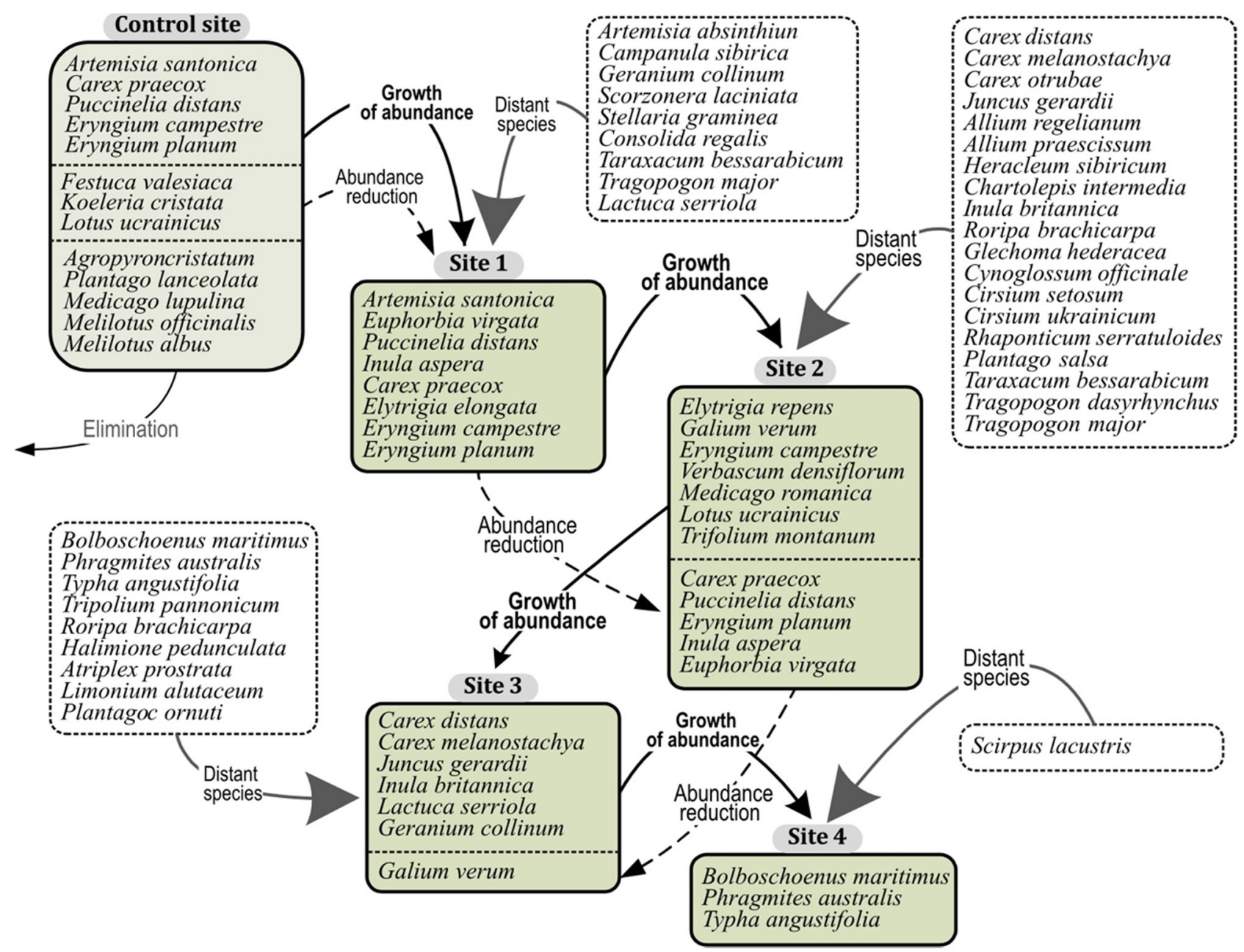

Fig. 5. Hypothetical scheme of the sequential formation of herbaceous plant communities in the different habitats of surface subsidence and flooding zone caused by underground coal mining on the territory of Western Donbass basin.

and abundance were created by specialists adapted to the wetland habitat (Bolboschoenus maritimus and Typha angustifolia) and halophytes (Carex distans, Juncus gerardii, Tripolium pannonicum, Halimione pedunculata, Atriplex prostrata, Limonium alutaceum, Plantago cornuti) as well. The contribution of generalists to plant richness and abundance in the meso-hygrophilic site was smaller and was provided mainly by the meadow halophytes Carex melanostachya and Geranium collinum, an inhabitant of wetlands Phragmites australis and ruderal species Inula britannica and Lactuca serriola. The hygrophilic habitat, which has an extremely high level of soil salinity, turned out to be suitable only for wetland specialists which achieved the greatest abundance here (Scirpus lacustris, Bolboschoenus maritimus, Typha angustifolia) and the generalist Phragmites australis, while other species were absent. Thus, in the most transformed habitat of the subsidence and flooding zone, species richness and abundance were provided by specialists, while sites with mesic conditions created suitable opportunities for the successful development of both specialists and generalists. A similar distribution of species had the structure of natural mosaic vegetation in the zone of spring marshes surrounded by semi-dry meadows (Hettenbergerová et al., 2013), which indicates some common features in the vegetation of fragmented territories.

Recovery of the target vegetation was not observed in all cases of spontaneous successions (Graf et al., 2008), and despite the rapid recolonisation of cut peatlands, the species composition was not the same as that observed in undisturbed bogs. At the same time, the other study of spontaneous successions in the territory of completed workings indicate that restoration of the

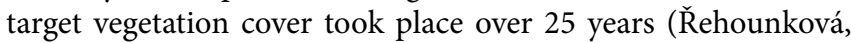
Prach, 2008; Trnkova et al., 2010; Prach et al., 2016).

Judging by the results of our work, in the area of underground mine workings, restoration of the target vegetation did not occur for 25 years of permanent subsidence and flooding, exacerbating transformation of the natural environment. Such a direction of succession cannot be expected due to the radical transformation of the landscape, hydrological regime and soil, the result of which is the formation of habitats that do not have similarities with the conditions of target vegetation existence. In addition, the transformed territory has a pronounced mosaic character, which contributes to the creation of local plant communities that are different from the neighbouring ones: the in- 
habitants of semi-dry and moist meadows, salt marshes and wetlands are adjacent at close distances. A similar local coexistence of several ecological groups of species was noted on undisturbed grasslands (Hettenbergerová et al., 2013; Fajmonová et al., 2020) and explained by the variable humidity conditions, which are accepted by many species, resulting in a species-rich community with a unique species composition. Based on the results of our studies, we built a proposed series of herbaceous plant synusia that could form on the territory where permanent subsidence of the surface and flooding occurred over a long period (Fig. 5).

\section{Conclusion}

Radical changes in herbaceous vegetation of the former pastures were determined by disturbance of soil and hydrological conditions in the subsidence and flooding area in the zone of working coal mines. Differences in the properties of transformed habitats contribute to the formation of dissimilar grassy communities on the neighbouring sites, including xerophytic steppe species, mesophytic meadow species, halophytes and wetland plants. At the same time, the restoration of semi-natural grasslands did not occur during the 25 years of ongoing flooding of the territory. The unusual species composition of vegetation in the flooded area is complemented by a significant number of rare and endangered herbaceous species that we have discovered. The potential ability of transformed territories to provide valuable habitats, such as wetlands or dry pastures, confirmed on disturbed mine landscapes (Kirmer et al., 2008; Trnkova et al., 2010), in combination with the right management methods, points to the prospects of revival of vegetation in the studied area of subsidence and flooding zones in Western Donbass.

\section{Acknowledgements}

This research work was supported by the Ministry of Education and Science of Ukraine, project number 0119 U100742.

\section{References}

Alexeyeva, A.A., Lykholat, Y.V., Khromykh, N.O., Kovalenko, I.M. \& Boroday E.S. (2016). The impact of pollutants on the antioxidant protection of species of the genus Tilia at different developmental stages. Visnyk of Dnipropetrovsk University. Biology, Ecology, 24(1), 188-192. DOI: $10.15421 / 011623$.

Baasch, A., Kirmer, A. \& Tischew S. (2012) Nine years of vegetation development in a postmining site: effects of spontaneous and assisted site recovery. J. Appl. Ecol., 49(1), 251-260. https://www.jstor.org/stable/41433345

Baranovski, B., Khromykh, N., Karmyzova, L., Ivanko, I. \& Lykholat Y (2016). Analysis of the alien flora of Dnipropetrovsk province. Biological Bulletin of Bogdan Chmelnitskiy Melitopol State Pedagogical University, 6(3), 419-429. DOI: 10.15421/2016113.

Baranovsky, B.O, Manyuk, V.V., Ivanko, I.A. \& Karmyzova L.A. (2017) Analysis of flora of the National Natural Park "Orilskiy" (in Ukrainian). Dnipro: Lira.

Bezrodnova, O.V. (2000). Spatial and temporal characteristics of grass biogeocenoses of the steppe Dnieper (in Russian). Ecology and Noospherology, 6(1-2), 126-131.

Bian, Z., Inyang, H.I., Daniels, J.L. \& Otto F. (2010). Environmental issues from coal mining and their solutions. Mining Science and Technology (China), 20(2), 215-223. DOI: 10.1016/S1674-5264(09)60187-3.

Bilz, M., Kell, S.P., Maxted, N. \& Lansdown R.V. (2011). European Red List of vascular plants. Luxembourg: Publications Office of the European Communities. DOI: 10.2779/8515.
Burke, A. (2018). Factors influencing colonisation processes in two contrasting mine sites in the Namib Desert. J. Arid Environ., 148, 78-81. DOI: 10.1016/j.jaridenv.2017.09.012.

Carter, M.R. \& Gregorich E.G. (2008). Soil sampling and methods of analysis. Boca Raton: CRC Press.

Cross, A.T., Young, R., Nevill, P., McDonald, T., Prach, K., Aronson, J., Wardell-Johnson, G.W. \& Dixon K.W. (2018). Appropriate aspirations for effective post-mining restoration and rehabilitation: a response to Kaźmierczak et al. Environmental Earth Sciences, 77, 256. DOI: 10.1007/ s12665-018-7437-z.

Čeplová, N., Lososová, Z., Zelený, D., Chytrý, M., Danihelka, J., Fajmon K. Láníková, D., Preislerová, Z., Řehořek, V. \& Tichý L. (2015). Phylogenetic diversity of central-European urban plant communities: effects of alien species and habitat types. Preslia, 87(1), 1-16.

Didukh, Y.P. (Ed.) (2009). Red Book of Ukraine. Plant World (in Ukrainian). Kyiv: Globalconsulting.

Ecological passport of Dnipropetrovsk province (2018) (in Ukrainian). Resourse: https://adm.dp.gov.ua/pro-oblast/rozvitok-regionu/ekologiya

Fajmonová, Z., Hájková, P. \& Hájek M. (2020). Soil moisture and a legacy of prehistoric human activities have contributed to the extraordinary plant species diversity of grasslands in the White Carpathians. Preslia, 92, 35-56. DOI: 10.23855/preslia.2020.035.

Fischer, J. \& Lindenmayer D.B. (2007). Landscape modification and habitat fragmentation: a synthesis. Glob. Ecol. Biogeogr., 16(3), 265-280. DOI: 10.1111/j.1466-8238.2007.00287.x.

Gorova, A., Pavlychenko, A., Kulyna, S. \& Shkremetko O. (2013). The investigation of coal mines influence on ecological state of surface water bodies. In G. Pivnyak, V. Bondarenko, I. Kovalevs'ka \& M. Illiashov (Eds.), Mining of mineral deposits (pp. 303-305). London: CRC Press. DOI: $10.1201 / \mathrm{b} 16354$.

Graf, M.D., Rochefort, L. \& Poulin M. (2008). Spontaneous revegetation of cutaway peatlands of North America. Wetlands, 28(1), 28-39. DOI: 10.1672/06-136.1

Herben, T., Chytry, M. \& Klimešova J. (2016). A quest for species-level indicator values for disturbance. J. Veg. Sci., 27, 628-636. DOI: 10.1111/ jvs. 12384 .

Hettenbergerová, E., Hájek, M., Zelený, D., Jiroušková, J. \& Mikulášková E. (2013). Changes in species richness and species composition of vascular plants and bryophytes along a moisture gradient. Preslia, 85(3), 369-388.

Hoch, P.C. (Ed.) (1999). Proccedings: XVI International Botanical Congress. Saint Louis held at American's Center. Saint Louis, Missouri, 1-7 August 1999. Paris: International Union of Biological Sciences.

Kirmer, A., Tischew, S., Ozinga, W.A., von Lampe, M., Baasch, A. \& van Groenendael J.M. (2008). Importance of regional species pools and functional traits in colonization processes: predicting re-colonization after large-scale destruction of ecosystems. J. Appl. Ecol., 45, 15231530. DOI: 10.1111/j.1365-2664.2008.01529.x.

Konvalinková, P. \& Prach K. (2010). Spontaneous succession of vegetation in mined peatlands: a multi-site study. Preslia, 82(4), 423-435.

Lykholat, Y.V., Khromykh, N.O., Didur, O.O., Alexeyeva, A.A., Lykholat, T.Y. \& Davydov V.R. (2018). Modeling the invasiveness of Ulmus pumila in urban ecosystems in conditions of climate change. Regulatory Mechanisms in Biosystems, 9(2), 161-166. DOI: 10.15421/021824.

Moreno-de las Heras, M., Nicolau, J.M. \& Espigares T. (2008). Vegetation succession in reclaimed coal-mining slopes in a Mediterranean-dry environment. Ecological Engineering, 34, 168-178. DOI: 10.1016/j.ecoleng.2008.07.017.

Mosyakin, S.L. \& Fedoronchuk M.M. (1999). Vascular plants of Ukraine a nomenclatural checklist. Kiev: M.G. Kholodny Institute of Botany.

Poulin, M., Rochefort, L., Quinty, F. \& Lavoie C. (2005). Spontaneous revegetation of mined peatlands in eastern Canada. Can. J. Bot., 83(5), 539-557. DOI: 10.1139/b05-025.

Prach, K., Tichy, L., Lencova, K., Adamek, M., Koutecky, T., Sadlo, J., Bartošova, A., Novak, J., Kovař, P., Jirova, A., Šmilauer, P. \& Řehounkova K. (2016). Does succession run towards potential natural vegetation? An analysis across seres. J. Veg. Sci., 27, 515-523. DOI: 10.1111/jvs.12383.

Prach, K., Tichý, L., Vítovcová, K. \& Řehounková K. (2017). Participation of the Czech flora in succession at disturbed sites: quantifying species' colonization ability. Preslia, 89(2), 87-100. DOI: $10.23855 /$ preslia.2017.087. 
Řehounková, K. \& Prach K (2006). Spontaneous vegetation succession in disused gravel-sand pits: role of local site and landscape factors. J. Veg. Sci., 17(5), 583-590. DOI: 10.1658/1100-9233(2006)17[583:SVSIDG]2. $0 . \mathrm{CO} ; 2$.

Řehounková, K. \& Prach K. (2008). Spontaneous vegetation succession in gravel-sand pits: a potential for restoration. Restor. Ecol., 16(5), 305-312. DOI: $10.1111 /$ j.1526-100X.2007.00316.x.

Sádlo, J., Chytrý, M., Pergl, J. \& Pyšek P. (2018). Plant dispersal strategies: a new classification based on the multiple dispersal modes of individual species. Preslia, 90(1), 1-22. DOI: 10.23855/preslia.2018.001.

Tarasov, V.V. (2012). Flora of Dnipropetrovsk and Zaporizhia provinces (in Ukrainian). Dnipropetrovsk: Lira.

Travleyev, A.P. (Ed.) (2010). Red Book of Dnipropetrovs'k Province (Plant World) (in Ukrainian). Dniproprtrovsk: VKK "Balance Club".

Travleyev, A.P., Belova, N.A. \& Zverkovsky V.N. (2005). Theoretical and practical aspects of forest reclamation on the territory of Western Donbass in Dnipropetrovsk region (in Ukrainian). Gruntoznavstvo, 16(1-2), 19-29.
Trnkova, R., Řehounkova, K. \& Prach R. (2010). Spontaneous succession of vegetation on acidic bedrock in quarries in the Czech Republic. Preslia, 82(3), 333-343.

Wilson, M.C., Chen, X.Y., Corlett, R.T., Didham, R.K., Ding, P., Holt, R.D., Holyoak, M., Hu, G., Hughes, A.C., Jiang, L., Laurance, W.F., Liu, J., Pimm, S.L., Robinson, S.K., Russo, S.E., Si, X., Wilcove, D.S., Wu, J. \& Yu M. (2016). Habitat fragmentation and biodiversity conservation: key findings and future challenges. Landsc. Ecol., 31(2), 219-227. DOI: 10.1007/s10980-015-0312-3.

Zelený, D. \& Chytrý M. (2019). Ecological specialization indices for species of the Czech flora. Preslia, 91 93-116. DOI: 10.23855/preslia.2019.093.

Zhang, J., Li, M., Taheri, A., Zhang, W., Wu, Z. \& Song W. (2019). Properties and Application of Backfill Materials in Coal Mines in China. Minerals, 9, 53. DOI: $10.3390 / \min 9010053$ 